\title{
Daži teorētiski jautājumi par atjaunojošā taisnīguma principu integrēšanu Latvijas krimināltiesību sistēmā
}

\author{
Mg. sc. soc. Uldis Mel̦ kisis \\ Rigas Stradina universitāte, \\ Juridiskā fakultāte, Latvija
}

\section{Kopsavilkums}

Autors rakstā atklāj savu skatỉjumu par atjaunojošā taisnīguma mērḳiem, par šìs koncepcijas principiem un problēmām, kas rodas, integrējot to pastāvošajā krimināltiesību sistēmā. Publikācijā tiek aktualizētas teorētiskas problēmas, ar kurām nācies saskarties citu valstu likumdevējiem, mēginot panākt efektīvu atjaunojošā taisnīguma sistēmas darbỉbu.

Atslēgvārdi: atjaunojošais taisnīgums, atjaunojošā taisnīguma mērḳi, atjaunojošā taisnīguma principi, krimināltiesību sistēma, izlīgums.

Raksta mērḳis ir atklāt problēmas, ar kurām jāsaskaras, integrējot atjaunojošā taisnīguma principus Latvijas krimināltiesību sistēmā.

Pētijumā izmantotās metodes: zinātniskās literatūras, normatīvo aktu un to projektu analīze.

Atjaunojošais taisnīgums kopš 1999. gada, kad ANO Ekonomisko un sociālo lietu padome (ECOSOC) apstiprināja rezolūciju par atjaunojošā taisnīguma pamatprincipu lietošanu kriminālnoziegumu sodos, ir ieguvis plašu izplatību pasaules attīstītajās valstīs. Ar šo brīdi un lēmumu, kurā tika apkopotas apmēram 30 gadu garumā paustās šīs koncepcijas filozofiski teorētiskās atziñas un veikta šo atziṇu eksperimentāla un praktiska pārbaude, atjaunojošais taisnīgums kḷuva par vispāratzītu krimināltiesiskās politikas realizācijas rekomendāciju. Izmainas, ko tas piedāvā, drīzāk uzskatāmas par konceptuāli jaunu pieeju gan konkrētu noziedzīgu nodarījumu radītā konflikta atrisināšanā, gan, kā rāda pieredze, kopējā noziedzības līmeṇa samazināšanā. Šìs izmaiṇas ir vērstas uz izlīguma panākšanu starp cietušo un likumpārkāpēju un ir saistītas ar alternatīvu ārpustiesas procedūru izstrādi un ieviešanu praksē. Runājot 
definīciju valodā, "Atjaunojošais taisnīgums ir process, kura gaitā likumpārkāpējs, cietušais un citas ieinteresētās puses vienojas, kā likvidēt nozieguma sekas" [3]. Atškirībā no tradicionālās krimināltiesību sistēmas, kuru bieži vien sauc arī par "represīvo sistēmu", atbilstoši principam, ka "vainīgajam jāsaṇem sods", atjaunojošā taisnīguma process ir saistīts ar noziedzīga nodarījuma seku likvidēšanu, turklāt - ne vien materiālu zaudējumu, bet arī emocionālu pārdzīvojumu iespējamu mazināšanu. Tādējādi šajā procesā būtisku lomu iegūst cietušais, ar kuru likumpārkāpējam jāpanāk ne vien juridisks izlīgums, bet arī jāsaņem piedošana un emocionāla samierināšanās. Tieši emocionālā sastāvdaḷa, kas tradicionālajā kriminālprocesā patiesībā nav iespējama, jo cietušā un likumpārkāpēja komunikācijas vietā drīzāk notiek prokurora un advokāta konfrontācija, atstāj vislielāko iespaidu uz likumpārkāpēja personību un vina turpmāko uzvedību. Pat pieņemot, ka likumpārkāpējs ir tik vien kā racionāla persona, kas ir ieinteresēta iespējami îsā laikā un ar iespējami mazākām turpmākajām saistībām (sodu) pārvarēt ar noziedzīgo nodarījumu saistītās sekas, viṇa aprēḳina diktētie apsvērumi atduras pret cietušã emocionālajām sāpēm, ko bez līdzjūtības un lïdzcietības izrādīšanas nevar mazināt.

No sabiedrības viedokḷa un iespējamajām sociālajām sekām raugoties, likumpārkāpēja emocionālais pārdzìvojums ir pat svarīgāks nekā pats izlīgums, kurā savā ziṇā ir ieinteresēts arī pats cietušais. Tad jau ḷoti vienkāršotā modelī un noliedzot noziedzīga nodarījuma sabiedrisko nozīmi, izlīguma risinājums būtu meklējams pie mums novārtā palikušajās deliktu tiesībās.

Zinātniskajā literatūrā bieži tiek uzdots savā ziṇā retorisks jautājums, kurā procesā - kriminālprocesā vai atjaunojošā taisnīguma procesā - iespējams sasniegt taisnīgāku rezultātu? Citiem vārdiem sakot - vai taisnīgākā reakcija uz izdarīto noziedzīgo nodarījumu ir likumpārkāpēja sodīšana vai viṇa samierināšana ar cietušo un nozieguma seku novēršana? Prakse parāda, un var minēt daudzus piemērus, ka ievērojami lielāku pozitīvu sociālo iespaidu atstāj tieši atjaunojošā taisnīguma procesā sasniegtais rezultāts. Tādējādi saistībā ar procesā sasniedzamajiem mērḳiem krimināltiesībām raksturīgais soda institūts ir kḷuvis par interesantas zinātniskās diskusijas priekšmetu arī atjaunojošā taisnīguma koncepcijas ietvaros. Daži zinātnieki uzskata, ka atjaunojošais taisnīgums ir process, kura mērḳis ir konstruktīvu un labprātīgu risinājumu atrašana [6]. Ja process neizdodas, tas ir jāatkārto [1], tas nevar būt sodošs [7], savukārt Ketlīna Deili [2] uzskata, ka atjaunojošais taisnīgums vairāk līdzinās sodam, jo likumpārkāpējam tas rada saistības. N̦emot vērā emocionālo pārdzīvojumu, ar kuru jāsaskaras likumpārkāpējam atjaunojošā taisnīguma procesā, un tā būtisko ietekmi uz likumpārkāpēja personību, daži autori uzskata šādu emocionālu pārdzīvojumu par soda alternatīvu. Acīmredzot patiesība ir kaut kur pa vidu, jo atjaunojošā taisnīguma process ietver gan labprātības principa ievērošanu, gan piespiedu elementus. Abi šie aspekti ir pietiekami svarīgi, lai tos paturētu prātā, integrējot atjaunojošā taisnīguma principus likumdošanā. Likumdevējam būtu jāsniedz atbilde uz jautājumu, vai atjaunojošais taisnīgums ir alternatīvs sods vai soda alternatīva? 
Teorētiski atjaunojošā taisnīguma sistēma var pastāvēt ārpus krimināltiesību sistēmas. Daži teorētiḳi pat to uzskata par alternatīvu pastāvošajai krimināltiesību sistēmai. Praksē šāda pilnībā autonoma sistēma tomēr nepastāv, un visbiežāk starp atjaunojošā taisnīguma elementiem un krimināltiesību sistēmu ir izveidotas noteiktas tiesiskas saites. Tās ir nepieciešamas, lai, piemēram, izvairìtos no soda vairākkārtīgas piemērošanas. Lielākas problēmas var rasties ar tiešu atjaunojošā taisnīguma procesa integrēšanu krimināltiesību sistēmā. Rodas jautājums, vai pastāvošie krimināltiesību standarti bez būtiskām izmaiņām var tik piemēroti arì atjaunojošā taisnīguma koncepcijas gadījumā? Droši vien, ka ne. Jo atjaunojošā taisnīguma koncepcijai ar tradicionālo krimināltiesību sistēmu ir vairāk atšḳirīgā nekā kopīgā. Atšḳirīgi tiek definēts noziedzīgā nodarījuma jēdziens, ir citi mērḳi un citāds process, dalībnieki un to lomas. Acīmredzot nav iespējams pastāvošos standartus bez būtiskas to pārskatīšanas un pārformulēšanas pieskaņot atjaunojošã taisnīguma filozofijai.

Arī vairāki atjaunojošā taisnīguma pamatelementi var pastāvēt un autonomi darboties ārpus atjaunojošā taisnīguma vai krimināltiesību sistēmas. Piemēram, alternatīvo strīdu risināšanas procedūra, ko visbiežāk saprot ar mediāciju, praksē ir atrodama arī dažādās nosaukumu variācijās, sākotnēji tika izveidota saistībā ar ārpustiesas strīdu izškirš̌anas procedūru ieviešanu civillietās un komerclietās. Lai arī šo procesu - atjaunojošā taisnīguma krimināltiesībās un mediācijas civiltiesībās un komerctiesībās - ieviešana pasaulē aizsākās gandrīz vienlaicīgi, tomēr to gaita visbiežāk norisinājās nesaistīti un paralēli dažādiem, jau sākotnēji atšḳirīgiem, mērḳiem.

Ja atjaunojošā taisnīguma mērḳiem jau nedaudz pieskārāmies, tad mediācijas ieviešanas mērḳis bija saistīts ar "taisnīguma pieejamības vienkāršošanu un uzlabošanu", sasaistot to ar naudas un laika resursu ekonomiju salīdzinājumā ar tiesu sistēmas procesu. Visbiežāk mediācijas sistēma tiek veidota kā pašregulatīva, ar efektīvu kvalitātes kontroles mehānismu, saglabājot mediācijas procesa elastību un iesaistīto pušu autonomiju. Tā tiek nodrošināta mediācijas efektīva, objektīva un kompetenta norise. Arī atjaunojošā taisnīguma process parasti tiek veidots kā pašregulējošs, balstìts uz pušu labo gribu. Praksē ir realizēti vairāki procesa norises modeḷi: mediācija (Victim Offender Mediation), izlīguma sanāksme (Conferencing / Family group conferencing), miera apḷi (Peace circles). Katram ir savas pozitīvās iezīmes un arī savi trūkumi. Latvijas gadījumā par pamatu būtu jāṇem mediācijas institūts, jo pasaulē jau ir izstrādāti un aprobēti procesa vadišanas principi, kuri ir visnotal piemēroti un atbilstīgi atjaunojošā taisnīguma procesam. Tomēr būtiskākā atšḳirība no klasiskā mediācijas institūta ir saistìta ar procesa dalībnieku loku. Klasiskos atjaunojošā taisnīguma procesos parasti piedalās arī sabiedrības pārstāvji, kuriem ir būtiska loma procesa veiksmīgā norisē. Diemžēl, nnemot vērā, ka Latvijā nav pilnvērtīgi attīstīta nevalstisko organizāciju kustība, jo tai ir ierobežota ietekme uz varas lēmumu pien,emšanu un realizāciju, paļauties uz šādu sabiedrisko aktivitāti būtu kḷūda. Tāpēc ir svarīgi atrast veidu, kā nodrošināt sabiedrības interešu aizsardzību, noziedzīgo nodarījumu neatkārtošanos un to cēloṇu likvidāciju. Daḷu šo funkciju savas kompetences ietvaros pilda Valsts probācijas dienests, 
bet tā ir tikai neliela dalıa no plašā problēmu loka, ar kuru jāsastopas, piemēram, veicot prevencijas darbu vai mēgeinot novērst identificētos nozieguma cēloṇus. Empīriski var pieṇemt, ka dạ̦a no šo problēmu risinājumiem būtu meklējami sociālā dienesta, bet vēl daḷa - policijas kompetences sfērā.

Lìdz ar to lietderīgi ir veidot grupas, kuras varētu izvietot pēc teritoriālās piekḷuves principa un kuras sastāvētu no probācijas dienesta, policijas un sociālā dienesta darbiniekiem. Ĺoti pozitīvi vērtējama policijas struktūras ietvaros jau veiktā prevencijas nodal̦as izveide un policistu norīkošana darbam noziegumu prevencijas jomā. Svarīgi, lai šādu grupu darbs būtu nodrošināts ar (kaut salīdzinoši nelieliem) finanšu resursiem, kurus varētu elastīgi izmantot prevencijas darbā un procesa nodrošināšanas nolūkā.

Vēlreiz atgriežoties pie atjaunojošā taisnīguma uzdevumiem, ir jākonstatē, ka, lai arī sākumā var šķist, ka šã procesa mērḳis ir acīmredzams, t. i., panākt izlīgumu starp cietušo un likumpārkāpēju, tomēr tā nav. Tā ir tikai procesa formālā puse. No sabiedrības viedokḷa raugoties, pat svarīgāk ir noskaidrot noziedzīgo nodarījumu cēloṇus, kurus sociālā atbalsta vai citu sociālo programmu ietvaros būtu iespējams novērst. Būtiska ir arī cietušã emocionālā ietekme uz likumpārkāpēju, jo tā bieži vien veicina likumpārkāpēja uzvedības maiṇu. Tādējādi atjaunojošā taisnīguma koncepcija ietver daudz plašāku iespējamo rezultātu sasniegšanu nekā izlīguma gadījumā.

N̦emot vērā lielo praktisko pieredzi atjaunojošā taisnīguma izmantošanā, šobrīd var jau runāt par zināmiem standartiem atjaunojošā taisnīguma regulējuma nosacījumos, kuri būtu jāṇem vērā, izstrādājot Latvijā šobrīd vēl pilnvērtīgi nepraktizējamo atjaunojošā taisnìguma sistēmu.

Turpinājumā apkopotas gan Eiropas Padomes (EP), gan ANO rekomendācijas, iekḷaujot arī Jaunzēlandes un Ziemeḷirijas likumdošanā iestrādātos atjaunojošā taisnīguma principus.

1. Piedalīšanās procesā ir pušu brīva griba. Attiecībā uz procesa pusēm ir jāsniedz pilnīga informācija par to tiesībām, par procesa norises kārtību un iespējamām sekām, par pušu tiesībām pārtraukt procesu jebkurā brīdī. Piedalīšanās nedrīkst tikt netaisnīgi stimulēta (EP, ANO).

2. Pamatfaktiem ir jābūt zināmiem abām pusēm. Atjaunojošā taisnīguma process var tikt pielietots tikai tad, ja nozieguma pierādijumi ir pietiekami (ANO); kad likumpārkāpējs atzīst vainu (Jaunzēlande, Ziemeḷirija).

3. Pārrunām ir jābūt konfidenciālām, un tās nevar tikt tālāk izmantotas, izṇemot pušu vienošanās nolūkā (EP, Jaunzēlande); pārrunas, kas nenotiek publiski, ir konfidenciālas (ANO). Iegūtā informācija nevar tikt izmantota par vainas pierādījumu sekojošā tiesas prāvā (EP, Jaunzēlande, ANO), kriminālprocesā (Ziemeḷîrija). Informācija par smagiem noziegumiem ir jānodod attiecīgajām varas iestādēm (EP).

4. Atjaunojošā taisnīguma process ir jānodrošina gan teritoriāli, gan visās kriminālprocesa stadijās (EP, ANO). 
5. Pusēm ir tiesības uz juridisku palīdzību un tulka palīdzību (EP, ANO); likumpārkāpējam ir tiesības uz juridisku palīdzību (Jaunzēlande, Ziemeḷīija). Nepilngadīgajiem ir tiesības uz vecāku piedalīšanos procesā (ANO, EP, Jaunzēlande, Ziemelīirija).

6. Lēmums nodot krimināllietu atjaunojošā taisnīguma procesā nāk no tiesībsargājošām iestādēm (EP). Atjaunojošā taisnīguma process nevar notikt, ja kāda no galvenajām iesaistītajām pusēm neizprot procesa nozīmi (EP). Procesa gaitā ir jānnem vērā dalībnieku būtiskas vecuma, brieduma, intelekta utt. (t. i., varas nevienlīdzības) atškiriības (EP, ANO), un tās jāṇem vērā arī vadot procesu (ANO).

7. Vienošanās rezultātam ir jābūt labprātīgam un tā elementiem - saprātīgiem un samērīgiem.

8. Tiesībsargājošām institūcijām ir jāsaṇem atjaunojošã taisnīguma procesa rezultātu novērtējums (EP, ANO), tām saprātīgos laika termiṇos ir jābūt informētām par notikušo (EP, Jaunzēlande), bet - tikai par rezultātu, nevis procesa saturu. Ja puses nepanāk vienošanos, tad bez vilcināšanās ir jāpien,em lēmums par tālāko rīcību (EP, ANO). Ja ir panākta vienošanās atjaunojošā taisnīguma procesā, tad tālāka sodīšana par konkrēto nodarījumu nav piel̦aujama (EP, ANO). Procesa izgāšanās vai vienošanās neizpildes gadījumā tas netiks izmantots sekojošajā kriminālprocesā (ANO).

9. Atjaunojošā taisnīguma process jāvada atbilstīgi atzìtiem standartiem, to saistot ar procesa virzitāju kompetenci un apmācību (sākotnējo profesionālo sagatavošanu) (EP, ANO), kā arī ar starpnieku zināšanu padzị̣ināšanu, pakalpojuma kvalitātes uzraudzību (EP), zinātnisko izpēti un pilnveidošanu (EP, ANO).

10. Atjaunojošā taisnīguma procesā starpniekam ir jāsaṇem visa informācija no tiesībsargājošajām institūcijām, jādarbojas objektīvi (EP, ANO), jānodrošina droša vide (EP, ANO) un jādarbojas efektīvi (EP, Jaunzēlande) [4].

Šeit jāpiemin vēl viena būtiska teorētiska problēma, kurai ir jāsniedz atbilde uz jautājumu, kā apvienot atjaunojošā taisnīguma "neformālo elastību" ne tikai ar krimināltiesību formālismu, bet arī ar visas likumdošanas regulējošo raksturu? Tà diezgan tieši ir saistīta ar jau ilgāku laiku pasaulē pastāvošo likumdošanas pieejas maiṇu, kas atzīst, ka sabiedrības attīstība un izmaiṇas tajā notiek strauji un procesi kḷūst pārāk sarežgiîti, lai regulējošã likumdošana (regulative law) spētu nodrošināt nepieciešamo attīstību. Šo sociālo izmainu dēl "regulējošā" likumdošana pamazām tiek nomainīta ar "reflekso" jeb principu likumdošanu (reflexive law) [5]. Prakse balstās uz to, ka likumdevējs nosaka tikai kopējos standartus vai vispārējos principus, kas virza procesa dalībnieku rīcību, vienlaicīgi atstājot pietiekami daudz brīvības procesu pašregulēšanās iespējai. Daudzās nozarēs (nodokḷu, vērtspapīru tirdzniecības u. c.) šãda likumdošanas pieeja pasaulē jau ilgāku laiku tiek veiksmīgi izmantota. Šajā tendencē iederas arī atjaunojošā taisnīguma koncepcija. 
Uldis Meḷkisis. Daži teorētiski jautājumi atjaunojošā taisnīguma principu integrēšanai Latvijas krimināltiesību sistēmā

\section{Secinājumi}

1. Atjaunojošā taisnīguma koncepcija pašlaik ir visefektīvākā sociālā prakse un līdzeklis kompleksai noziedzības problēmas risināšanai.

2. Šobrīd var uzskatīt, ka Latvijā ir izveidoti atjaunojošā taisnīguma koncepcijas darbībai nepieciešamie tiesību institūti. Tomēr process drīzāk notiek nevis pozitīvas un progresīvas ārvalstu pieredzes pārṇemšanas rezultātā, bet gan ES prasību dēḷ. Trūkstot vietējās politikas veidotāju gribai un, iespējams, arī atjaunojošā taisnīguma koncepcijas pilnvērtīgai izpratnei, šo institūtu darbība drīzāk notiek autonomi, un to darbība nav vērsta uz koncepcijas ietvaros formulēto mērḳu sasniegšanu.

3. Pieaugošās sociālās sistēmas sarežginitības dēḷ, konstruējot jaunus tiesību imstitūtus vai tiesiskās uzvedības modeḷus, ir jārēḳinās ne tikai ar tiesību sistēmas “iekšējiem parametriem”, bet, iespējams, pat svarīgāk - jāveic izpēte un jāizprot dažādu regulējumu atšḳirīgā ietekme uz sociālajām sekām.

4. Dažādās valstīs pastāvošās atšķirīgās atjaunojošā taisnīguma sistēmas apliecina, ka neeksistē viens vienīgs pareizais tiesību institūtu izveidošanas variants. Svarīgāka ir šo institūtu darbības efektivitāte un to sociālā ietekme.

\section{Some Theoretical Questions on Restorative Justice Principles' Integration in Criminal Justice System of Latvia}

\section{Abstract}

The author reveals his vision of restorative justice objectives, concepts and principles of the problems that arise by integrating the existing criminal justice system.

The article acentuates theoretical problems encountered in other countries by legislators trying to achieve an effective restorative justice

Keywords: restorative justice, goals in restorative justice, restorative justice principles, criminal justice system, conciliation.

\section{Literatūra un avoti}

1. Braithwaite, J. Restorative justice: assessing optimistic and pessimistic accounts. Vol. 25, 1999.

2. Daley, K. Revisiting the relationship between retributive and restorative justice. In: J. Braithwaite (Ed.), Restorative justice: philosophy to practice. Aldershot, USA, Singapore, Sydney: Ashgate/ Dartmouth, 2000.

3. Judins, A. Izlīgums Latvijas krimināltiesībās. Providus / Valsts probācijas dienests, 2005. 
Uldis Meḷ kisis. Daži teorētiski jautājumi atjaunojošā taisnīguma principu integrēšanai Latvijas krimināltiesību sistēmā

4. Shapland, J., Robinson, G., \& Sorsby, A. Restorative justice in practice: evaluating what works for victims and offenders. Routledge, 2011.

5. Teubner, G. Substantive and reflexive elements in modern law. Law and Society Review, 1983; 17.

6. Walgrave, L. Community service as a cornerstone of a systemic restorative response to juvenile crime. In: G. Bazemore (Ed.). Restorative juvenile justice: repairing the harm of youth crime. Monsey, NY: Criminal Justice Press, 1999.

7. Wright, M. Justice for victims and offenders: a restorative response to crime. $2^{\text {nd }} \mathrm{ed}$. Winchester: Waterside Press, 1996. 